\title{
Social Status of a Woman in Hinduism and Reason for Abusive Attitude of Hindus Towards Women in India
}

\author{
Mumtaz Ahmed Jasvi \\ Department of Islamic Studies, Lahore Garrison University, Lahore, Pakistan \\ Email address: \\ scholarjasvi@gmail.com \\ To cite this article: \\ Mumtaz Ahmed Jasvi. Social Status of a Woman in Hinduism and Reason for Abusive Attitude of Hindus Towards Women in India. \\ International Journal of Science, Technology and Society. Vol. 9, No. 5, 2021, pp. 216-221. doi: 10.11648/j.ijsts.20210905.12
}

Received: May 31, 2021; Accepted: September 10, 2021; Published: October 21, 2021

\begin{abstract}
A woman has significant role in a society. After birth, every new born baby gets moral, social and religious values from his parents. A mother transfers her character into her children. Personalities needed by a society for future handling are initially prepared by women, it is an obvious reality. An educated, healthy (physically and psychologically) and well-mannered woman can only be beneficial for her nation. Women in Hindu (Indian) society hold same position or status as have in other societies. But unluckily, they are not treated as are in other societies. In both ways, in some characters; a woman is dealt as goddess (Devi) but on the other hand she is treated as an evil creature. With the passage of time, a lot of revolutionary changes have occurred in the social status of women in Hindu society. In this modern age even, they have got a lot of social rights but in some remote areas of India, they are still being ill-treated by their family members, society and public institutions. Women are deprived from basic rights. They are sacrificed for the sake of so-called religious beliefs. After consulting the available data on this topic, I felt that the status of women in Hindu (Indian) society needs to be elaborated. The main purpose of this study is to highlight the current status of women enjoying in India (Hindu society). The basic research question has been raised, how women are dealt in a Hindu Society? The research methodology used for this study is descriptive, prescriptive and analytical. For this study, qualitative research methodology is used.
\end{abstract}

Keywords: Women, Social Behavior, Basic Rights, Harassment, Exploitation

\section{Introduction}

Hinduism is an old religion among world religions. Its origin and originator are unseen. It is reality that it flourished in Indus valley after the composition of different beliefs, social as well as cultural values and regional civilization. "The word Hindu is derived from the name given to the people who settled on the banks of the river 'Sindhu' (Indus in northern India). The name was corrupted to Hindu over the course of time, and so their system of beliefs was given the name Hinduism." [1] A Hindu (Indian) society is a complex society which contains different cultures and religions. Hindus of this society hold different beliefs, philosophical concepts and social values. They believe in superstitions and have made spontaneously a set of beliefs which are being practiced by Hindu even in this modern age. Due to caste system people have been divided into social classes; high and low. "The caste system organized society according to class and occupation, and one's place in this system determined the way one was supposed to behave in society." [2]

The status of a woman in Hindu Society or Hindu religion is fluctuated and unbalanced. Somehow, women are given the status of a powerful personality but on the other hand they are not treated like a human being and have to face some worst situations. In old Hindu literature; Hindu Upanishads, women were considered a sacred personality. "Hindus believe in a large number of gods and goddesses (female gods). Each has a different personality and controls a different aspect of life." [3] The character of Sita was presented as a respectable and honorable lady. She was presented as a good life partner of Ram. "The earlier history of Hinduism showed a much more positive attitude to women." [4] But at the same time, women were sacrificed for the sake of some religious beliefs. Sati Practice is famous in Hindu society in which a woman when she becomes widow has to die or by force, she was burnt alive with dead body of her late husband. Women were not given proper social status or basic rights by their families. They have no property rights 
morally or legally in old Hindu societies. Even some Hindus have a belief that a woman is cause of evil or an un-touchable creature. In Manu (a sacred book of Hinduism), women were advised to surrender themselves before the supremacy of man in the form of daughter, wife and widow of their late husbands. A woman having male baby has more respect and status in a Hindu family and also in a Hindu Society. A male baby is considered beneficial for their society. He will earn and would financially support their parents on the other hand a woman after her marriage has to migrate to other families. This is the idea behind giving the preferences to a male baby. For women, when someone's husband died, they had to face very brutal attitude by her society.

In modern Hindu (Indian) society, still they are not enjoying proper social, legal and basic rights. In their early ages when they are in fetus of their mothers, they are aborted after gender detection. In their childhood, they are harassed even by close relatives. Marriages in early ages, honor killing and acid burning incidents are high in ratio in India. Practically, they are being exploited and deprived in different areas even some laws have been formulated for the welfare of women in India. The status of a woman has changed as compared to past status. Women are working in every field of life and are free to get every kind of education. A revolutionary change has occurred in the behavior of men toward women due to social awareness and deep influences of different kinds of media. People's general behavior and attitude have changed negative to positive due to uses of social media by women especially girls related to different fields. But still in some remote areas' women are being dealt as they were in old times. There is need to highlight those areas or beliefs which are depriving women from their basic rights. Moreover, there is need to introduce a number of reforms to upgrade the status of women in India and to give them safety from deprivation as well as exploitation.

\section{Women in Hindu (Hinduism) Society}

Males are preferred by Hindu parents in India due to many reasons. Females are comparatively deprived and not given basic rights as are given to males. They are not welcomed on their birth as compared to males. So, it is necessary to highlight those aspects in which women are being deprived and men are granted. Some are so critical and complex in nature. Some are un-social and illegal but are being practiced by Hindus generally in India. These aspects can be elaborated with the following points.

\subsection{Status Before Birth / Sex-Selective Abortion}

In these days, parents are informed about type of gender of new born baby at initial stage. Due to advance technology, it is confirmed by doctors or ultrasonic process whether baby is male or female. So, to get a gender according to their own will has become very critical issue in many societies. In many societies male baby is preferred. To get a male baby, many parents abort at the early stage of pregnancy when it is confirmed that the baby is female. In India, there are many causes of selective abortion; fetus may be defective physically. If there may be some critical situations for mother so they abort. In some cases, parents don't want female baby as are aborted in India. The sex-selective baby is got in upper class family mostly those can afford the expenses of all this procedure. "According to studies on female feticide, urban and upper income groups, who have access to medical facilities; utilize these to practice their preference for the desired sex of their child. The sharper decline in the urban birth sex ratio at the all-India level, as in many other states is." [5]

In India, it is assumed that male baby is preferred for some social reasons. They consider that a male baby is a cause of their family progress. They assume that a girl cannot handle many social issues. Females are considered that after marriage they have to leave their parental home with the heap of dowry. Mostly males run the system of houses and handle financial matters assumed by Hindus. For these reasons in Hindu society, they are preferred. For females, dowry is given by parents but parents of males demand a long list of houses holding accessories at the time of marriages. Males get a lot of gifts (dowry) and support the family financially. Males are considered to be the source of income for their family so they are given preferable status as compared to women in Indian society. For this reasons, female embryos are killed at early stages. After marriage, every woman is demanded to give birth of a male baby. "The degradation of women commences from their birth. Whilst every Hindu wife is most anxious to have sons, daughters are seldom prayed for, nor is their advent welcomed." [6]

\subsection{Status in a Family as Different Relations}

A woman was not treated properly in Hinduism in Brahmin period. She was deprived the basic rights even by her family and her society. She was not given some proper social status in a society. Also, her family exploited her in different ways. "There were aspects of the dharma's stras, such as their inferior treatment of women and members of lower castes." (p. 114) [18].

But nowadays, a lot of changings have been occurred in the policies about women in Hinduism. Many social policies have been changed into the favor of women. Many reforms have been taken place in the reaction of women's movements and struggles for their basic rights. "The reformers used these references as a basis to advocate education for both men and women as a necessary basis for an ideal Hindu society." (p. 111) [2]. Many other activities like child marriage, Sati, permanent widowhood and secluded way of life were rejected by women of Hinduism. Their service and struggle created a positive role in Hindu society and their positive image was appreciated. They were remembered as Mother India and Bharat Mata in an honorable and respectable ways.

By legislation, in India, they were given proper rights as men are given by rules but practically, they are deprived and exploited in different ways. "The laws of India attempt to give women's equal rights, but there is a great difference between laws on the books and common practices." (p. 1989) [6]. Women living in less privilege areas are more oppressed 
and exploited as compared to the developed areas of Hindu society. In these areas where orthodox Hindus are living, they exploit them in different ways. In laws book of Manu women are degraded socially, in which they were compelled to accept the dictation of man in the form of a power full personality. Some of stories of women victimized by men are quoted "Manu's attitude to women in general and then looking at stories about several individual females: a goddess who flees from her husband, a Brahmin woman rejected by her husband and a forest-girl seduced and abandoned by a king." [7] According to Hindu belief a woman has to be obedient to her husband and this act would be counted as great religious and ritual practice. Women have to obey the orders of their husband in every situation. "To obey the husband is to obey the Vedas." (p. 207) [6].

\subsection{Education and Social Training}

Education for everyone (male and female) is a primary right given by every society. People who don't keep some discriminatory behavior between genders are ranked in developed countries nowadays. In those countries or nations, both males and females are trained and taught the basic social norms and cultural beliefs. Women in those societies work shoulder to shoulder with men. Many social tasks are done by women properly those are considered to be unapproachable for them. They are working in many social institutions; in the field of education, in hospitals, business institutions, public dealing offices, armed forces and so on. All these depend upon their proper training and education in some better institutions. The education policy for women in Hinduism is not same as it was mentioned in old literature. In old Hindu literature, women were bounded not to learn the sacred texts or Holy books. They were forbidden not to read the Vedic literature. Only men of special caste and category used to learn and can further preach it. "The Upanishads do not unequivocally support the view that neither Sudras nor women could receive the teachings of the Vedas." [8]

This phenomenon is also elaborated by modern scholars who have studied Hindu literature comprehensively. Wendy Doniger explained in his book named "The Hinduism an alternate History" in which he wrote, "Women were forbidden to study the most ancient sacred text." [9] In many societies, a lot of activities are done only by women. No men can perform them properly. In medical and educational system women are preferred to teach the girls and to treat them. Some parents want to make their children study male from male teachers and females from female teachers. On primary level both male and female children are preferred that they should study under the supervision of female staff and teachers. They have a belief, "If women were not to study, where will the teachers, for Girls' schools come from?[10] In India for the educational purposes, many movements and personalities (particular women) struggled for the woman education. For, to give proper education is a fundamental right of every woman of a society. Without education women can't socially grow up. "It was due in part to the efforts of Subbalakshmi's family and the work of other women like Bangalore Nagaratnammal, Balasaraswati, and Rukmini Devi Arundale that the fields of education and performing arts opened up for Hindu women in the twentieth century." [11] In India, this was the time when modernization of women was introduced by some Hindu women. Their enthusiastic and motivational activities empowered the Indian women to face the social challenges and to resolve their issues. From these activities changed the behavior of orthodox people. They were forced to think about women's prosperity and rights.

\subsection{Marriage, Dowry and Divorce}

Marriage is a word generally used when a new couple is made legally by a society with the mutual consideration and understanding of parents of both male and female or taken place in a court. The process of marriage is different in different societies, regions and religions. A marriage ceremony is performed in the presence of a religious man in different cultures and civilizations. It is actually, an agreement that both male and female after marriage would live with harmony, love and mutual understandings. They will be responsible for the next generation; for caring, protecting, feeding, social training and future handling. In India it is practiced in the presence of a Panduit. Some activities are performed on the base of religious beliefs. "Cosmological bodies are also drawn, especially the Sun and the Moon. Mandapa Kolams are the large floor designs drawn exclusively for marriage ceremonies. Made with wet rice paste, these kolams add sanctity to the marriage hall." [12] Due to different social classes in India, there is great difference in marriage ceremonies. There is great difference between upper and lower classes in arrangements as well as in styles.

In past, some literal clues tell us about the customs of Hindu marriages. "The origin of Madhubani paintings is believed to be during the period of Ramayana, when the king of Mithila told people of his kingdom to paint walls and floors of their houses on the marriage of Sita and Rama. The people believed that doing so should please the Gods." (p. 259) [12]. Many terms were used for marriage ceremony in Hinduism and Hindu society. Such as "Gandharva", "Vivaha" and "Kanthi badal" are named in different social classes. Some ritual practices are performed in front of Idol of Krishna in the presence of Hindu pundit at the time of marriage ceremony in a Hindu society. In Hinduism, some symbols (pure religious) are declared for married women like applying Sandor, wearing Manga sutra. In India, bangles in the arms of women are worn so that they seemed married. Red clothes are worn by females in Hindu society at the time of marriage ceremony but nowadays this trend is being changed as the world is getting globalization. People of different countries, societies and religions are becoming close to one another socially. Arranged marriages are mostly practiced in Hindu families but in past and in modern age, love marriages are also being practiced and celebrated as mentioned in Mahabharata the love story of Dushyanta and Shakuntala.

At the time of women's marriages, the parents of women 
give some gifts to their daughters, it is called dowry but nowadays particularly in Hindu society, it has achieved a dangerous form. Dowry has become an essential part of marriage. Parents of males' demand before marriage ceremony a list of gifts in the form of dowry. In different forms; in cash, in the shape of building, furniture, Jewelry, vehicle and other home appliances are demanded from male side, it has to fulfill by female parents and relatives. Sometimes parents can't afford dowry. Many danger consequences have to face by women. "Thousands of young brides perished each year in India because of dowry, or the lack of it heartlessly killed some crushed to death, some thrown out of high buildings, others strangled or poisoned, many burned like so much refuse." [13] For these reasons, in many countries it has been banned legally due to worst consequences. In India, there is great difference between law and practical situation in this regard.

Marriage dissolution by men is called divorce. In Hindu societies the authority of divorce is given to men only. In most societies both men and women have rights to nullify the marriage agreement with their mutual understanding and also by force, using legal rights or by court process. Divorce is also used to finish the marriage agreement even it is not liked in many societies. In Hindu society it is also discouraged socially because after divorce the children are affected and victimized dangerously. Remarriage is also permitted in Hindu society and for social purposes in some ways it is encouraged. "Not only is divorce accepted as a Hindu custom, but remarriage with the possibility of the mutual choice between the spouses, as well as the establishment of a marriage contract, seem to offer an escape from the rigidity of the orthodox Brahmana model of Hindu marriage." [14]

In the perspective of a religion, marriage in Hindu society is considered a part of Karma Philosophy which is the basic belief in Hinduism. For this reason, many activities are performed in the presence of a clergy man at the time of marriage ceremony. Polygamy in India is prohibited legally according to the marriage act of 1955 . But according to the religious scripture and laws books on Hinduism not only it was permitted but also practiced by many Hindu Lords, Kings and warriors. The people who are in the favor of polygamy view that this act was in special situations. "The Hindu Law books (dharma shastras) made provision for polygamy and certain marriage relationships under special circumstances not for the purpose of carnal pleasures but for the protection and continuation of family lineage." [15] Historically, it is proudly narrated by Hindu scholars that Ram's father Dasharatha had three wives named Kausalya, Sumitra and Kaikeyi, Krishna had eight wives, Soma the moon god had twenty seven wives and Vasudeva the father of Krishna had fourteen wives respectively.

\subsection{Widowhood and Sati Practice}

A widow was treated in different ways in different periods in Hindu religion and society. A woman in Hindu society was mostly deprived and exploited socially when her husband died in her life. Sometimes a widow was properly treated but, in many cases, she has to face very critical situations. She had to die with her husband on his funeral ceremony. For this purpose, a custom Sati is famous in Hindu society even this practice is now being discouraged in modern Hindu society (India). Actually, the idea of sati was promoted by Hindu religious men. "The idea of sati has long been a central feature in the Western image of India. Suttee, as Westerners have often spelled the word, describes the ritual according to which a Hindu wife follows her husband to his death by ascending his pyre with him or ascending one of her own shortly afterward." [16] On the behalf of marriage agreement that a woman would be with her husband in seven circles (turns) of their birth so she has to live and die with her husband. "The permanence of the sacred tie can furthermore survive the lifetime of the husband when the Sati, i.e., the self-sacrifice of the widow on the pyre of her dead husband, is seen as the expected duty of the Hindu wife." (p. 03) [16]. In modern Hindu society, this practice is being condemned and strongly opposed by moderate Hindus. Now it is considered to be the deprivation of basic rights of a woman and also remarriage is arranged publicly for divorced as well as for a widow. It is the matter of moderate and orthodox thinking of Hindus in modern period. Some are in the favor of Sati and some are strongly opposite to this practice. "Some Hindus thought that it is a good idea for some women to burn themselves to death on their husbands' funeral pyres, while other Hindus strongly disagree" [9].

\subsection{Property and Inheritance Rights}

Like other social rights, the property rights for women are not clear in Hinduism. Women are given the property rights. Somehow in Hindu religious scriptures it is mentioned that women can get ownership only those things which they can wear, eat or hold easily. "The Laws of Manu classify jewelry as one of the main types of women's property, which she has the right to give to her offspring or bring to her marriage." [17] Women's economical rights are determined in different societies. In Vedic literature, it is mentioned that women's property right are those things which are easily handled by women. Women can control them properly in every situation. These would be their property. Women rights in property (inheritance), wealth left by late husband or other blood relative in case of their deaths are not determined as are granted to women in other religions or societies.

\subsection{Status of a Woman in Religious Practices}

In Hinduism, the status of a woman in ritual practices is very critical. In both ways; she is treated as a goddess and also a cause of evil deeds. In Hindu mythology, "women are the root of evil." (p. 58) [9] This situation or position of women is not by nature or due to anti-women policies of Hindu societies. But it may the result of perceptions and misunderstanding of Hindu scholars or clergy men. Women are treated in start, in Hinduism, as a goddess or Devi but with the passage of time some practices and policies were adopted by extremist Hindus and they propagated them in 
their societies such kinds of ideas. These policies are unnatural and inhuman for a common man and also for women. "Of particular interest in the return to the golden past was a search for a time when women held a more exalted position than at present." [18] In past, women were not treated in proper ways in Hindu society. They were sacrificed on the base of so-called social or religious customs. But nowadays in modern period, women have achieved their proper status and valuable rank in Hindu society.

Only the places in India where still literacy rate is low and people are not aware of basic social rights of women, they are ignoring them in every walk of life. "Women as a group have always been oppressed in India (as elsewhere), but individual women have always succeeded in making their mark despite the obstacles." (p. 36) [9]. In start, women were forbidden to learn the sacred text. They were not allowed to be a leading personality in a religious practice. But this trend has been changed with the passage of time. Now women are learning and practicing different religious activities in-door and out-door in some temples. So, the religious status of women in Hindu society has been improved as compared to previous decades.

Not only men in Hindu society but also women adopt such practices which are considered to be under asceticism. They participate in yoga exercises. They also involve themselves in Tapasya. Some women adopt a strict life style as if they are Sadhus. In Hinduism and also in a Hindu society, women's contribution in ascetical activities cannot be ignored. In some conditions, they adopt social as well as un-social way of life that is usually rejected by a society. This life style affects a society in deep ways. A woman if rejects the sexual life then it affects genetic progress, in the worst ways. In a Hindu society, women for the cause of religious purposes or to get some spiritual ends do such activities which are adopted by men. They don't care for their private parts to cover them. They become Sādhvī, Sannyasin and female Brahma Charis. This style leads them towards a strict way of life. "Women becoming masculinized through their ascetic lives not only affected themselves but impacted on society: just as it was seen as remarkable for them to behave in a 'male' way by giving up sex, so men appearing in any way 'womanly' was unusual and unacceptable.” [19] Normally, a woman handles all domestic matters in most societies. But when she gives up all these activities, she actually is not playing her role in a society. So, in a Hindu society, due to women's anti-social activities, social set up is being destroyed. Females in India, are already facing many problems, their quittance from social setup is creating many critical issues for them. Rape cases are increasing day by day. To fulfill their basic needs, they have to beg door to door. Their social status is also being degraded due to their irresponsible behaviors. Like animals, they are being sacrificed for religious purposes in some Hindu societies.

\section{Conclusion}

Hindu religion has not given proper status to women. Just the wives of Lords who proved loyal to their husbands were given the status of Devi. But generally, women were not given suitable rank in a Hindu society. They were advised to accept the supremacy of men. In early ages, their marriages were declared. To become loyal to their husbands, Sati practice was advised for women. The status of women or their position in Hindu society is improving day to day. It is due to influences of mass and social media. After social awareness, Hindus of different areas of India have changed their behavior towards women from negative to positive. But still in some remote areas, women are not being treated in proper ways. Some old beliefs are still being practiced by extremist Hindus and their attitudes with women are same as were in old times. Abortion rate is high in Indian society. Sexual harassment and acid burning cases are high in ratio as compared to other countries. Still widow is not liked to be married by anybody in this society. Property rights have not been determined for women. Dowry has become a social curse in Indian society. A lot of suicide incidents have been noted by national and international media that parents having shortage of money can't afford money so girls before and after marriages commit suicides.

\section{Recommendations}

To improve the status of women in Indian (Hindu) society, a lot of reforms are needed to introduce. Proper education and awareness for both males and females are necessary without discrimination. Abortion at after detection of female baby should be legally banned in Indian otherwise the ratio of females would be decreased as compared to male's ratio. Women in every walk of life should be given the opportunities to do work. Forced marriages should be nullified. The concept of dowry in Indian society should be vanished so that suicide or killing incidents can be prevented. For this purposes, strict legislation is required by Indian government. The unfavorable religious beliefs are needed to be reviewed by religious scholars and their nature should be for the favor and prosperity of women. All basic rights: social, property, legal and family should be determined by law in Indian constitutions so that women exploitations can be minimized. Mass media should play his role in upgrading the status of women in Indian as well as in Hinduism. UNO can play his role in structuring policies to make women secured and safe from acid burning, honor killing, Sati practices and marriages in early age.

\section{References}

[1] Palmer, M. (2004). World Religions, London: Harper Collins Publishers, p. 144.

[2] Smart, N. (1999). Hinduism, $1^{\text {st }}$ ed., London: Rout Ledge Publishers, p. 32.

[3] Encyclopedia Britannica, Religions around the World, 2008, p. 9. http://www.britannica.com

[4] Flood, G, Hinduism, $1^{\text {st }}$ ed., New York: Black Well Publishing, p. 37. 
[5] Patel, T. (2007). Sex-Selective Abortion in India, $1^{\text {st }}$ ed., New Delhi: Sage Publication Pvt, p. 96.

[6] Wilkins, W. J. (1887). Modern Hinduism, $2^{\text {nd }}$ ed., London: Curzon Press, P. 189.

[7] Doniger, W. (2014). On Hinduism, New York: Oxford University Press, p. xv.

[8] Lal, V. (2010). Introducing Hinduism, London: Icon Books Ltd, p. 31.

[9] Doniger, W. (2009). The Hindus, an Alternative History, New York: The Penguin Press, p. 26.

[10] Richards, G. (1985). Modern Hinduism, $1^{\text {st }}$ ed., London: Curzon Press, p. 45.

[11] Pintchman, T. (2007). Women's Lives, Women's Rituals in Hindu Traditions, New York: Oxford University Press, p. 184.

[12] Singhania, N. (2018). Indian Art and Culture, $2^{\text {nd }}$ ed., Chennai: McGraw Hill Education, p. 259.
[13] Bantwal, S. The Dowry Bride, 82, retrieved from http://www.kensingtonbooks.com, on April 15, 2019.

[14] Holden, L. (2008). Hindu Divorce, (England: Ash gate Publishing Limited, p. 125.

[15] Hinduism and Polygamy, Retrieved from July 09, 2019. https://www.hinduwebsite.com/hinduism/h_polygamy.asp

[16] Hawley, J. S. (1994). Sati: The Blessing and Curse, New York: Oxford University Press, p. 3.

[17] Patton, L. L. (2002). Jewels of Authority, New York: Oxford University Press, p. 3.

[18] Flood, G. (2003). The Blackwell Companion to Hinduism, New York: Blackwell Publishing, p. 50.

[19] Hunt, H. (2012). Clothed in the Body, London: Ash gate Publishing Limited, p. 65. 